\title{
The Genesis of Street Law in South Africa
}

Professor David Jan McQuoid Mason

Professor of Law, Director of the Centre for Socio-Legal Studies, University of KwaZulu-Natal, Durban and President of the Commonwealth Legal Education Association

In 1984, while Dean of the Faculty of Law at the University of Natal, during a visitor's programme sponsored by the United States Information Service (USIS), I met Ed O'Brien of Georgetown University Law Faculty, Washington DC, a co-founder of the American Street Law programme. I invited him to South Africa in 1985 and his trip was paid for by USIS. It was an inauspicious time as President PW Botha declared a State of Emergency the day Ed arrived in the country to conduct non-racial Street Law workshops with me. He and I brainstormed a curriculum with a multi-racial group of high school teachers and pupils and then persuaded the President of the Association of Law Societies, Graham Cox, with assistance from the Attorneys Fidelity Fund, to provide financial backing for a pilot Street Law programme for South Africa - the first such programme outside of the United States.

In 1986 a pilot Street Law programme under Mandla Mchunu was set up at the University of Natal (Durban) to operate in five schools - according to the apartheid context: two African and two white schools and one Indian school. The programme was a success and soon expanded to 16 other universities with financial assistance 
from the Attorneys Fidelity Fund. The Fund continued to sponsor the programme until South Africa's transition towards democracy in the early 1990s, when funding ceased.

After the release of Nelson Mandela in 1990, the South African Street Law programme decided to introduce South Africans to the Universal Declaration of Human Rights. With assistance from an American civic education school teacher, Eleanor Greene, and field-testing by the 16 Street Law Coordinators, Ed and I produced a workbook, together with an instructor's manual, in the South African street-law format, entitled Human Rights for All. I was the general editor and coordinator of the project which was done in partnership with Lawyers for Human Rights (of which I was Durban chairperson at the time) and Street Law Inc. (then the National Institute of Citizen Education under the Law (NICEL)). An American version of the book was subsequently published in 1996.

In 1992, with assistance from the United States Agency for International Development (USAID), the Centre for Socio-Legal Studies (CSLS) in partnership with NICEL decided that it was necessary to introduce South Africans to the principles of democracy in preparation for the country's first democratic elections. The local Street Law team met with the 26 NGOs involved in voter education in KwaZulu-Natal and they agreed to work together to produce a workbook on democracy. The NGO contribution was to help design the curriculum for the programme and to field- test the materials in their constituencies. Over a period of a year the CSLS coordinated the process and student text on democracy was produced, together with an instructor's 
manual, entitled Democracy for All. There was consultation with, and field-testing by, the 26 NGOs and 16 Street Law Coordinators throughout the process. The writing team consisted of two Americans (Ed O'Brien and Mary Curd Larkin of NICEL and three South Africans (Mandla Mchunu of CSLS, Karthy Govender and myself - I also acted as editor - all of us from the then University of Natal, (now the University of KwaZulu-Natal)). One spin-off from the book was the development by Chuck Scott and the Centre for Socio-Legal Studies of the Democracy Challenge Game which required players to identify and define 13 different signposts of democracy using interactive techniques in a board game involving quizzes and debates. The game was field-tested in over 500 high schools in South Africa and has been translated into Swahili. It has also been adapted to embrace the Convention of the Rights of the Child in Nigeria. A new edition of Democracy for all is being published this year.

In 1997 I began assisting, together with Ed, Mary Curd Larkin and Bebs Chorak of Street Law Inc. and the Ford Foundation and Open Society Institute, to develop Street Law programmes and materials and provide workshop training in Eastern and Central Europe, Central Asia and the former Soviet Union. The countries involved in the project were Albania, Belarus, Croatia, the Czech Republic, Estonia, Hungary, Kazakhstan, Kyrgyzstan, Latvia, Macedonia, Moldova, Mongolia, Romania, Russia, Slovakia, Ukraine and Uzbekistan. The programme was aimed at assisting the countries to develop cadres of school teachers, law students and law teachers who could teach and develop indigenous curricula and materials on Street Law, human rights and democracy for inclusion in the formal school curriculum. My experience 
in dealing with the transition from apartheid to democracy in South Africa resonated strongly with the countries that were undergoing the transition from communism and dictatorship to democracy. By the end of 2001 Street Law, human rights and democracy materials had been published by Belarus, Croatia, the Czech Republic, Estonia, Kazakhstan, Kyrgyzstan, Latvia, Macedonia, Moldova, Mongolia, Russia, Slovakia, Ukraine and Uzbekistan. In addition Human Rights for All and Democracy for All were translated into Croatian, Mongolian and Russian. Democracy for All was also translated into French for use in Haiti by Civitas International, and later adapted into Arabic by Street Law Inc.

The Street Law books, Human Rights for All and Democracy for All have also been used in Street Law, human rights and democracy workshops in Egypt, Haiti, Lesotho, Zimbabwe, Zambia, Namibia, Mozambique, Tanzania, Uganda, Ghana, Nigeria, Morocco, Ethiopia, India and Bangladesh. In addition they have been used in British Commonwealth Secretariat human rights workshops in Tanzania, Lesotho, Uganda, Mozambique and in an annual African Human Rights Education camps in different parts of Africa. Street-law programmes in one form or another exist in Kenya, Uganda, Nigeria and Ghana.

The support given to the initial founding of the South African Street Law programme by the Attorneys Fidelity Fund, and the subsequent funding of the South African Democracy for All Street Law programme for the decade since 1992, primarily by the USAID, has paid handsome dividends. In 2003 Street Law South Africa (Street Law SA) was established as a not-for-profit company and has been accredited by the Sector 
Education and Training Authority (SETA) as a service provider. Lindi Coetzee, the current Street Law National Coordinator, is applying to the South African Qualifications Authority (SAQA) for approval of a Street Law unit standard. These steps are being taken to ensure that Street Law SA becomes more self-sustaining and less dependent on donor funding.

The South African Street Law programme has produced valuable tools for the teaching of law, human rights and democracy to civil society, particularly school children, university students, school teachers, prison officials and police officers, as well as community groups. Aspects of it have been successfully replicated in a number of developing countries ranging from Africa, Asia and the Caribbean to Eastern and Central Europe, Central Asia and the former Soviet Union, as well as the United States itself.

The consolidated South African Street Law Learner's and Educator's Manuals (2015) published by Juta \& Co. Ltd., are now in their third edition, and the Street Law SA materials and learning methodologies remain a valuable resource that could be mainstreamed into the South African school curricula in line with the country's international obligations. 